\title{
PENGARUH PERBEDAAN MEDIA FILTER DALAM RESIRKULASI TERHADAP KUALITAS AIR, PERTUMBUHAN DAN KELANGSUNGAN HIDUP BENIH IKAN MAS (Cyprinus carpio)
}

\section{The Effect Of Differences Filter Media In Recirculation On Water Quality, Growth And Survival Rate Of Goldfish (Cyprinus Carpio)}

\author{
Fevi Adi Pratama ${ }^{1}$, Helmi Harris ${ }^{2 *}$, Syaeful Anwar ${ }^{3}$ \\ ${ }^{1}$ Prodi Ilmu Perikanan, Fakultas Perikanan dan Kelautan Universitas PGRI Palembang \\ ${ }^{2}$ Magister Teknologi Pangan, Sekolah Pascasarjana Universitas Djuanda Bogor \\ ${ }^{3}$ Prodi Budidaya Ikan, Fakultas Perikanan dan Kelautan Universitas PGRI Palembang \\ * Corresponding author: helmiharris76@yahoo.com
}

\begin{abstract}
ABSTRAK
Ikan mas (Cyprinus carpio) merupakan salah satu komoditas ikan air tawar yang memiliki potensi besar untuk dikembangkan guna memenuhi gizi masyarakat. Keberhasilan budidaya ikan mas dipengaruhi oleh factor kualitas air. Kualitas air sebagai media pemeliharaan ikan mas dapat menurun dengan cepat karena aktifitas yang dilakukan oleh ikan seperti sisa feses dan sisa pakan yang mengendap didasar air. Penggunaan zeolit dalam pengolahan air merupakan salah satu cara untuk mengurangi zat pencemaran yang terlarut dalam air. Penelitian ini dilaksanakan selama 30 hari pada Bulan Februari hingga Maret 2018 bertempat di Unit Balai Benih Ikan Gandus Kota Palembang. Pengujian kualitas air dilakukan di Balai industry dan standardisasi Palembang. Penelitian menggunakan Rancangan Acak Lengkap (RAL) dengan 3 (tiga) taraf perlakuan, masing-masing perlakuan dilakukan 3 (tiga) kali ulangan, yaitu P1 (Zeolit 25\% dan pasir), P2 (Zeolit 50\% dan ijuk), dan P3 (Zeolit 75\% pasir dan ijuk). Wadah yang digunakan dalam penelitian ini adalah akuarium yang berukuran $40 \mathrm{~cm} x$ $25 \mathrm{~cm} \times 30 \mathrm{~cm}$. Hasil penelitian menunjukkan bahwa P3 (Zeolit 75\% pasir dan ijuk) memberikan hasil terhadap kualitas yaitu suhu $25-29^{\circ} \mathrm{C}$, pH 5-7, Oksigen terlarut 2,182,90, dan amonia 0,06-0,10 dan memberikan hasil terbaik yaitu pertumbuhan panjang sebesar 10,71 cm, pertambahan bobot sebesar 8,86 gram dan kelangsungan hidup sebesar $100 \%$.
\end{abstract}

Kata kunci : Ikan Mas, Kualitas Air, Pertumbuhan, Kelangsungan Hidup, Zeolit.

\section{ABSTRACT}

Goldfish (Cyprinus carpio) is one of the freshwater fish commodities that has great potential to be developed to meet community nutrition. The success of goldfish cultivation is influenced by water quality factors. The quality of water as a medium for maintaining goldfish can decline rapidly due to the activities carried out by fish such as fecal waste and feed residue that settles on the bottom of the water. The use of zeolites in water treatment is one way to reduce pollution dissolved in water. This research was conducted for 30 days from February to March 2018 at the Palembang City Gandus Fish Seed Center Unit. Water quality testing was carried out at the Industrial Center and Standardization in Palembang. The study used a completely randomized design (CRD) 
with 3 (three) levels of treatment, each treatment was carried out 3 (three) times, namely P1 (25\% Zeolite and sand), P2 (50\% Zeolite and palm fiber), and P3 (Zeolite 75\% sand and palm fiber). The container used in this study is an aquarium measuring $40 \mathrm{~cm} \times 25$ $\mathrm{cm} \times 30 \mathrm{~cm}$. The results showed that P3 (Zeolite 75\% sand and palm fiber) gave results on quality, namely temperature 25-290C, pH 5-7, dissolved oxygen 2.18-2.90, and ammonia 0.06-0.10 and gave results. The best was growth in length of $10.71 \mathrm{~cm}$, weight gain of 8.86 grams and survival of $100 \%$.

Keywords: Goldfish, Water Quality, Growth, Survival, Zeolite.

\section{PENDAHULUAN}

Ikan mas (Cyprinus carpio) adalah salah satu jenis ikan air tawar yang sangat disukai olah masyarakat, karena rasa dagingnya yang enak dan bergizi tinggi. Seiring berkembangnya pengetahuan masyarakat akan pentingnya sumber protein bagi pertumbuhan, maka kebutuhan ikan mas konsumsi dari tahun ke tahun terus meningkat seiring dengan bertambahnya jumlah penduduk. Hal tersebut berdampak pada peningkatan produktifitas budidaya ikan mas secara intensif dimana kualitas air menjadi permasalahannya. Kualitas air sebagai media pemeliharaan dapat menurun dengan cepat karena aktifitas yang dilakukan oleh ikan seperti sisa feses dan juga sisa pakan yang mengendap di dasar air.

Untuk mengatasi permasalahan tersebut, diperlukan teknologi yang dapat menunjang produktifitas budidaya ikan mas. Menurut Helfrich dan Libey (2000) dalam Suandi (2019) sistem resirkulasi akuakultur (Recirculation Aquaculture System) dengan teknik filtrasi dalam budidaya ikan merupakan salah satu upaya yang dapat diaplikasikan untuk menanggulangi penurunan kualitas air. Penggunaan sistem ini karena memiliki kelebihan yaitu penggunaan air yang sedikit, fleksibilitas lokasi budidaya, budidaya yang terkontrol dan lebih higienis, kebutuhan akan ruang atau lahan relatif kecil, kemudahan dalam mengendalikan, memelihara dan mempertahankan suhu serta kualitas air.
Selain menggunakan system resirkulasi, penggunaan filter untuk perbaikan kualitas air juga wajib dilakukan. Salah satu filter yang digunakan adalah zeolite. Menurut Silaban et al (2012), zeolit adalah suatu senyawa mineral aluminosilikat yang dikenal memiliki daya adsorpsi yang baik serta memiliki nilai kemampuan tukar kation sebesar 200-300 cmolc/100 gram. Terdapat berbagai macam zeolit dan salah satunya adalah zeolit alam jenis klinoptilolit memiliki afinitas yang tinggi terhadap amoniak dan telah berhasil digunakan sebagai pembersih amoniak pada sistem akuakultur air tawar.

Berdasarkan uraian tersebut, maka dilakukan penelitian ini yang bertujuan untuk mengetahui pengaruh perbedaan media filter dalam resirkulasi terhadap kualitas air, pertumbuhan dan kelangsungan hidup benih ikan mas (Cyprinus carpio).

\section{METODE PENELITIAN \\ Waktu dan Tempat}

Penelitian ini dilakukan pada bulan Februari hingga Maret 2018, dilaksanakan di Balai Benih Ikan (BBI) Gandus Kota Palembang. Pengujian kualitas air dilakukan di Balai Riset Industri dan Standardisasi Palembang Bahan Dan Alat

Bahan yang digunakan dalam penelitian ini antara lain ikan mas, zeolite, pasir, ijuk, pakan komersil dan air. Sedangkan Alat yang digunakan 
akuarium, thermometer, $\mathrm{pH}$ meter, kamera digital, skopnet, alat tulis, timbangan digital, pompa air, selang dan baskom.

\section{Metode Penelitian}

Penelitian ini dilakukan pada bulan Februari hingga Maret 2018, dilaksanakan di Balai Benih Ikan (BBI) Gandus Kota Palembang. Pengujian kualitas air dilakukan di Balai Riset Industri dan Standardisasi Palembang Bahan Dan Alat

Bahan yang digunakan dalam penelitian ini antara lain ikan mas, zeolite, pasir, ijuk, pakan komersil dan air. Sedangkan Alat yang digunakan akuarium, thermometer, $\mathrm{pH}$ meter, kamera digital, skopnet, alat tulis,

timbangan digital, pompa air, selang dan baskom.

\section{Metode Penelitian}

Metode penelitian yang digunakan yaitu eksperimental menggunakan Rancangan Acak Lengkap yang terdiri dari 3 taraf perlakuan dan 3 kali ulangan. Adapun perlakuan dalam penelitian ini adalah sebagai berikut :

P1 : Resirkulasi dengan perlakuan zeolit $25 \%$ dan pasir

P2 : Resirkulasi dengan perlakuan zeolit $50 \%$ dan ijuk

P3 : Resirkulasi dengan perlaakuan zeolit $75 \%$ pasir dan ijuk.

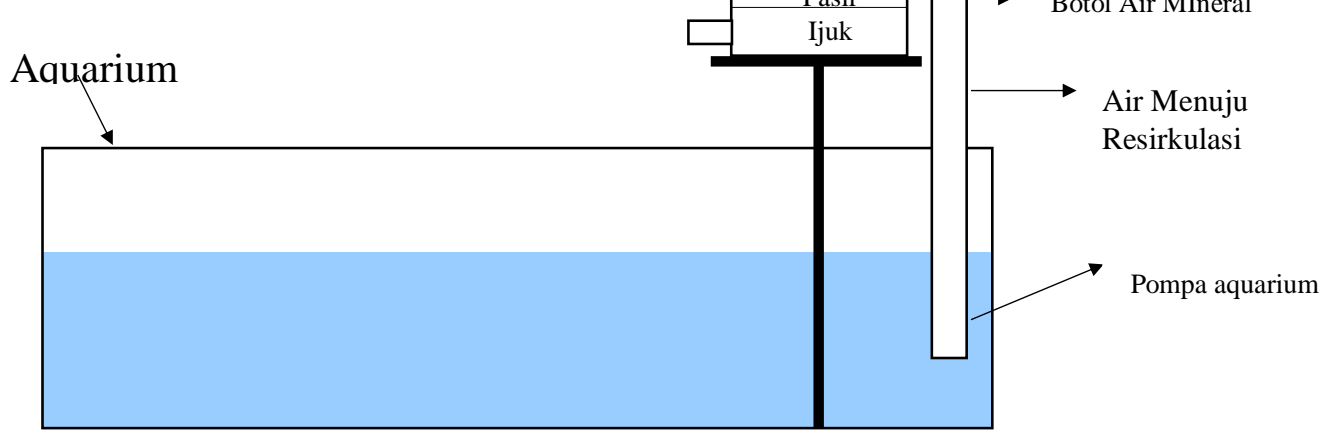

Gambar 1. Konstruksi Sistem Resirkulasi

Sistem resirkulasi (Gambar 1) pada penelitian ini mengunakan pompa aquarium mini sp 1200. Air yang berada pada aquarium dialirkan melaui pompa langsung menuju pipa dan kemudian menuju media filter resirkulasi yaitu zeolit, pasir, ijuk. Setelah melalui filter tersebut, air yang sudah tersaring langsung masuk kembali ke dalam media pemeliharaan yaitu aquarium yang berisi ikan Mas (Cyprinus carpio) dengan padat tebar 10 ekor.

\section{Parameter Pengamatan}

Kualitas Air

Parameter kualitas air yang diamati selama penelitian dilakukan yaitu $\mathrm{pH}$ dengan menggunakan $\mathrm{pH}$ meter, suhu dengan menggunakan thermometer, amoniak dengan

menggunakan spektrofotometer dan selanjutnya oksigen terlaut (DO) menggunakan DO meter. Pengukuran $\mathrm{pH}$ dan suhu dilakukan setiap hari selama 24 jam pagi, siang, dan sore hari. Sedangkan 
pengukuran amoniak dan DO dilakukan pada awal, dan akhir penelitian.

\section{Pertumbuhan Berat dan Panjang}

Data pertumbuhan diambil dengan cara mengukur panjang dan bobot ikan. Data diperoleh melalui pengamatan setiap 7 hari sekali selama 30 hari, setiap pengamatan benih diambil 10 ekor benih ikan Mas (Cyprinus carpio) per wadah atau setiap ulangan. Cara mengukur pertumbuhan dengan mengunakan rumus sebagai berikut :

Perhitungan pertambahan biomassa mutlak dihitung mengunakan rumus Effendi, (1997), yaitu

$$
W=W T-W O
$$

Keterangan :

W : Biomassa hewan uji (gr)

Wt : Bobot hewan uji pada akhir penelitian (gr)

Wo : Bobot hewan uji pada awal penelitian (gr)

Perhitungan pertumbuhan panjang mutlak dihitung mengunakan rumus Effendi, (1997), yaitu

$$
P m=P t-P o
$$

Keterangan :

Pm : Pertambahan panjang rata-rata ikan (gr)

Pt : Panjang rata-rata ikan pada akhir penelitian (gr)
Po : Panjang rata-rata ikan pada awal penelitian (gr)

Perhitungan kelangsungan hidup ikan mengunakan rumus dari Effendi (1997), yaitu :

$$
\mathrm{SR}=\frac{N t}{N o} X 100 \%
$$

Keterangan :

SR : Kelulusan hidup (\%)

$\mathrm{Nt}$ : Jumlah hewan uji pada akhir pemeliharaan

No : Jumlah hewan uji pada awal pemeliharaan

\section{Analisis data}

Data hasil pengamatan yang diperoleh dianalisis secara statistika dengan menggunakan Analisa sidik ragam (ANSIRA), Jika hasil yang diperoleh dinyatakan F-hitung < $\mathrm{F}$ tabel 5\% disebut berpengaruh tidak nyata, sedangkan jika $\mathrm{F}$ hitung > $\mathrm{F}$ tabel $5 \%$ disebut berpengaruh nyata. Apabila $\mathrm{F}$ hitungnya nyata atau sangat nyata, maka dilakukan uji lanjut. Uji lanjut yang digunakan jika nilai $\mathrm{KK}$ yang diperoleh (Hanafiah, 2011).

\section{HASIL DAN PEMBAHASAN Hasil}

Pengamatan kualitas air yang dilakukan selama penelitian meliputi $\mathrm{pH}$, suhu, oksigen terlarut (DO), dan Amonia $\left(\mathrm{NH}_{3}\right)$. Data yang diperoleh dari pengujian sampel setiap perlakuan dapat dilihat pada Tabel 1 berikut ini.

Tabel 1. Parameter Kualitas Air Selama Penelitian

\begin{tabular}{lllll}
\hline \multirow{2}{*}{ Perlakuan } & \multicolumn{4}{l}{ Rata-Rata Parameter } \\
\cline { 2 - 5 } & Suhu $\left({ }^{\mathbf{}} \mathbf{C}\right)$ & Ph & DO $\left(\mathbf{m g L}^{-\mathbf{1}}\right)$ & Amoniak $\left(\mathbf{m g l}^{-1}\right)$ \\
\hline P1 & $27-29$ & $7,4-7,6$ & $2,53-3,50$ & 0,08 \\
P2 & $27-29$ & $7,4-7,6$ & $2,88-2,93$ & 0,10 \\
P3 & $27-29$ & $7,4-7,6$ & $2,59-2,76$ & 0,08 \\
\hline
\end{tabular}


Suhu air selama penelitian pada setiap perlakuan berkisar antara $27^{\circ} \mathrm{C}$ $29^{\circ} \mathrm{C}$. Kisaran suhu tersebut di duga merupakan kisaran optimal untuk pertumbuhan ikan mas. Wihardi, et al (2014) mengatakan bahwa suhu air sangat mempengaruhi laju pertumbuhan, laju metabolisme ikan dan nafsu makan ikan serta kelarutan oksigen dalam air. Lebih lanjut Kordi dan Tancung (2005) menambahkan bahwa laju pertumbuhan meningkat sejalan dengan kenaikan suhu, dimana suhu dapat menekan kehidupan ikan bahkan menyebabkan kematian bila kenaikan suhu naik drastis.

Pengamatan $\mathrm{pH}$ air selama penelitian benih ikan Mas (Cyprinus carpio) pada semua perlakuan $\mathrm{P} 1, \mathrm{P} 2, \mathrm{P} 3$ berkisar antara 7,4 hingga 7,6. Nilai $\mathrm{pH}$ tersebut berada dalam kisaran yang baik untuk kehidupan ikan mas (Cyprinus carpio). Hal ini dikuatkan oleh Santoso (1993) dalam Arisanti et al., (2013); Effendi (2003) dalam Ramadhan et al (2020) yang mengemukakan bahwa derajat keasaman yang optimal untuk ikan mas berkisar antara 6,5-8,5.

Oksigen terlarut (DO) selama penelitian berkisar 2,53 sampai dengan 3,50. Nilai DO tersebut masih dapat mendukung kehidupan ikan mas. Trewavas (1982) dalam Supriaddin, et al (2013); Yufika, et al (2019) menyarankan kadar oksigen terlarut adalah > $3 \mathrm{mg} / \mathrm{l}$ untuk ikan mas. Lebih lanjut Mundeng, et al (2013) dalam Haris (2018) mengatakan bahwa biota air membutuhkan oksigen guna pembakaran bahan bakarnya (makanan) untuk menghasilkan aktifitas, seperti aktifitas berenang, pertumbuhan, reproduksi, dan sebaliknya.

Nilai amonia selama penelitian menunjukkan nilai yang optimal untuk pertumbuhan ikan mas (Cyprinus carpio) dimana nilai amonia pada masingmasing perlakuan berkisar antara 0,08 hingga 0,10. Menurut Syaifudin, et al (2004) dalam Hafiz (2020); Effendi (2003) dalam Arianto (2019), konsentrasi amonia terlarut yang dapat ditoleransi baik untuk kelangsungan hidup ikan adalah berkisar antara 0.04- $3.01 \mathrm{ppm}$. Selain itu Nurhidayat (2009) dalam Suandi (2019) juga menambahkan bahwa zeolit mempunyai sifat mampu menyerap limbah ammonia dengan struktur rongga yang teratur dan sebagai media menempelnya mikroorganisme (biofilm) yang dapat memanfaatkan berbagai unsur yang tersuspensi dalam air dan diserap bersama sebagai bahan makanan organisme tersebut. Hasil pengamatan terhadap peningkatan pertambahan bobot benih ikan Mas (Cyprinus carpio) pada masing-masing perlakuan dapat dilihat pada Gambar 2 berikut ini.

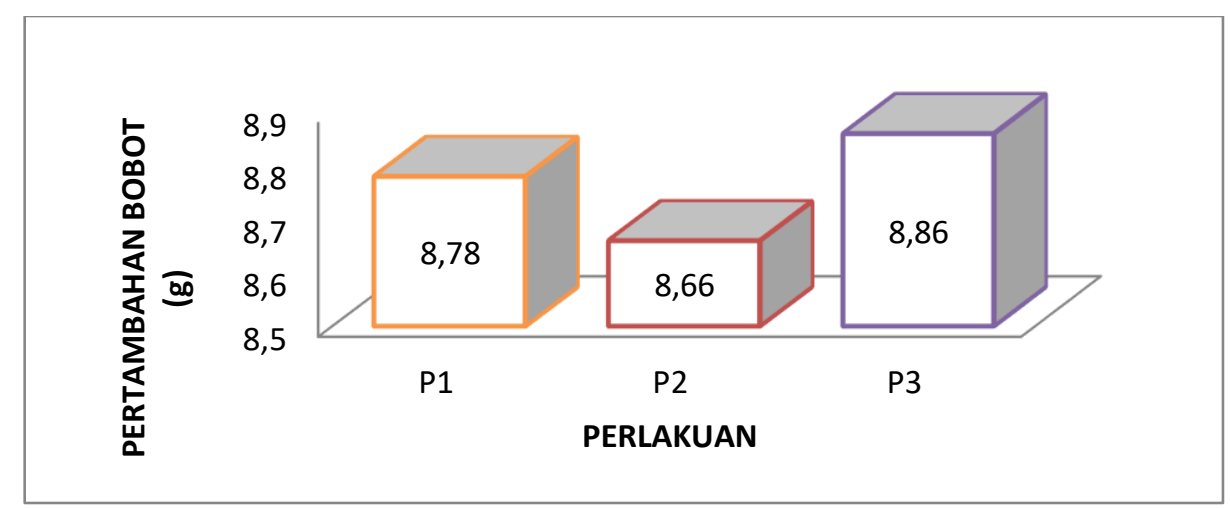

Gambar 2. Pertambahan Bobot Rataan Perlakuan Benih Ikan Mas

(Cyprinus carpio) selama pengamatan. 
Berdasarkan pada Gambar 2 di atas menunjukkan nilai pertambahan berat bobot rata-rata tertinggi terdapat pada perlakuan P3 (Zeolit $75 \%$ pasir dan ijuk) sebesar 8,86 gram, diikuti dengan perlakuan P1 (Zeolit 25\% dan pasir) yaitu sebesar 8,78 gram, dan perlakuan P2 (Zeolit 50\% dan ijuk) yang terendah yaitu sebesar 8,66 gram. Namun secara perhitungan statistik didapatkan $\mathrm{F}_{\text {hitung }}<$ $\mathrm{F}_{\text {tabel }}$ dengan tingkat kepercayaan 5\% dengan nilai 3,424 $<5,14$ yang berartinya secara statistik ke 3 perlakuan tersebut menunjukkan berpengaruh tidak nyata antar perlakuan. Nilai perlakuan P3 (zeolit $75 \%$ pasir dan ijuk) untuk tingkat pertambahan bobot memperoleh nilai tertinggi dari perlakuan lain diduga karena selama masa pemeliharaan jumlah pakan yang diberikan dapat direspon dengan baik oleh benih ikan mas (Cyprinus carpio) dan tidak terdapat sisasisa pakan pada media pemeliharaan serta adanya pengaruh dari hasil filterisasi yang baik oleh pasir dan ijuk. Hal ini diperkuat oleh Lesmana (2004) yang mengatakan bahwa resirkulasi (perputaran) air dalam pemeliharaan ikan berfungsi untuk membantu keseimbangan biologis dalam air, menjaga kestabilan suhu, membantu distribusi oksigen serta menjaga akumulasi atau mengumpulkan hasil metabolit beracun sehingga kadar atau daya racun dapat ditekan. Selain itu Lovell (1988) dalam Mulyadi, et al (2014) juga menambahkan bahwa pertambahan bobot tubuh ikan menunjukkan bahwa kandungan energi dalam pakan yang dikonsumsi ikan melebihi kebutuhan energi untuk pemeliharaan dan aktivitas tubuh lainnya.

Lebih lanjut Effendi (1979) menyatakan bahwa pertumbuhan individu dapat terjadi apabila ada kelebihan energi dan protein yang berasal dari makanan, yang telah digunakan oleh tubuh untuk metabolisme dasar, pergerakan, perawatan bagian tubuh dan mengganti sel-sel yang rusak. Sedangkan pada perlakuan P2 (Zeolit 50\% dan ijuk) didapatkan hasil pertambahan bobot terendah dibandingkan perlakuan P3 (Zeolit 75\% pasir dan ijuk) dan P1 (Zeolit $25 \%$ dan pasir) yaitu dengan bobot akhir 8,66 gram. Hal ini diduga pada perlakuan P3 (Zeolit 50\% dan ijuk) proses filterisasi menggunakan ijuk belum optimal sehingga mengakibatkan nafsu makan ikan berkurang dan terganggunya sistem metabolisme. Hal ini diperkuat oleh Mulyadi et al., (2014) yang menyatakan bahwa selain pakan yang mencukupi, kualitas air di dalam media pemeliharaan juga sangat mendukung pertumbuhan ikan.

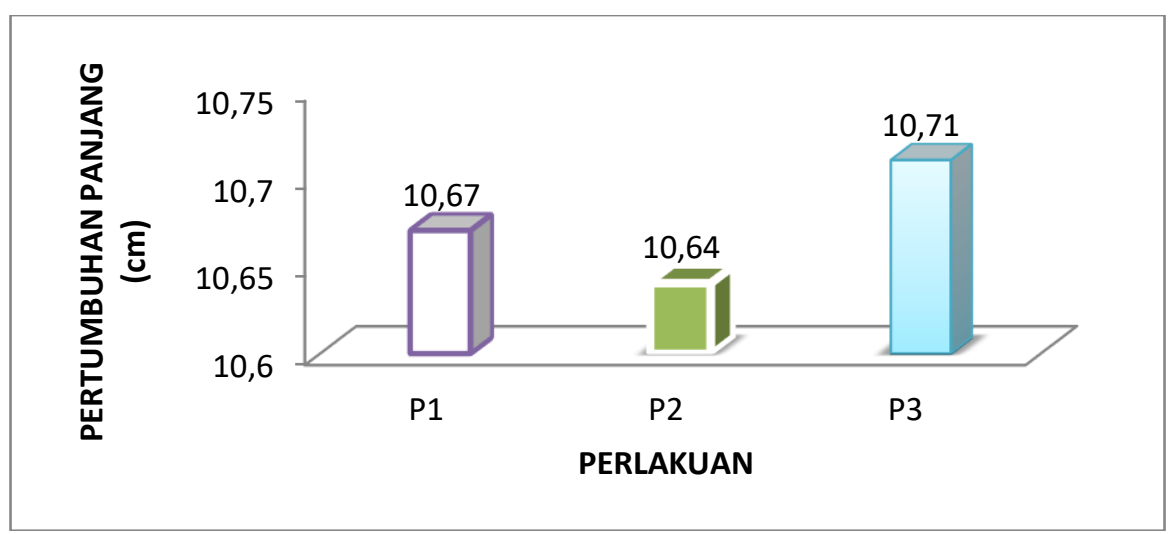

Gambar 3. Grafik Pertumbuhan Panjang Rataan Perlakuan benih Ikan Mas

(Cyprinus carpio) selama pengamatan. 
Dari Gambar 3 menunjukkan nilai pertumbuhan panjang rataan tertinggi terdapat pada perlakuan P3 (Zeolit $75 \%$ pasir dan ijuk) yaitu sebesar $10.71 \mathrm{~cm}$, diikuti perlakuan P1 (Zeolit 50\% dan pasir) sebesar 10,67 cm dan P2 (Zeolit $25 \%$ dan ijuk) sebesar 10,64 cm. Sedangkan secara pengujian statistik diperoleh pertumbuhan panjang benih ikan Mas (Cyprinus carpio) dengan perlakuan yang berbeda menunjukkan $\mathrm{F}_{\text {hitung }}<\mathrm{F}_{\text {tabel }}$ dengan tingkat kepercayaan $5 \%$ dimana $1,00<5.14$ yang berarti secara statistik berpengaruh tidak nyata antar perlakuan.

Perlakuan P3 (Zeolit 75\% pasir dan ijuk) menunjukkan nilai yang tertinggi yaitu $10,71 \mathrm{~cm}$. Hal ini diduga P3 (Zeolit $75 \%$ pasir dan ijuk) bahwa proses filterisasi menggunakan pasir dan ijuk memberikan hasil yang optimal sehingga menghasilkan kualitas air yang bagus di dalam media pemeliharaan dan pemberian pakan dalam jumlah yang sesuai dengan pertumbuhan ikan. Menurut Mujiman (2002), laju pertumbuhan dipengaruhi oleh suhu air, persedian pakan, komposisi makanan, ruang gerak, persediaan oksigen dan hasil buangan metabolisme. Sedangkan untuk perlakuan P1 (Zeolit 50\% dan pasir) yang pertumbuhannya lebih rendah dibandingkan dengan perlakuan P3 (Zeolit $75 \%$ pasir dan ijuk) dan lebih tinggi dari P2 (Zeolit 25\% dan ijuk) yaitu sebesar 10,67 cm. Hal ini diduga adanya perbedaan pertumbuhan benih ikan Mas
(Cyprinus carpio) yang tidak merata sehingga terjadinya persaingan dalam perebutan pakan yang menyebabkan ukuran yang berbeda serta filterisasi menggunakan pasir yang cukup baik dalam pengelolaan kualitas air. Sedangkan hasil pengamatan menunjukkan nilai yang terendah terdapat pada perlakuan P2 (Zeolit 50\% dan ijuk) yaitu $10,64 \mathrm{~cm}$. Hal ini diduga penggunaan filterisasi menggunakan zeolite $50 \%$ dan ijuk belum cukup optimal dikarenakan bentuk ijuk yang kasar dan pada umumnya ijuk digunakan untuk media penetas telur atau substrat. Hal ini diperkuat oleh Edwar, et al (2016) yang menyatakan substrat yang baik yaitu penggunaan substrat ijuk sebagai media penetas telur. Lebih lanjut Wijayanti (2014) menyatakan bahwa pertumbuhan merupakan proses hayati yang akan berlangsung didalam tubuh ikan, pertumbuhan akan terjadi apabila jumlah makanan yang dikonsumsi ikan melebihi kebutuhan pemeliharaan tubuh. Hal ini juga diperkuat oleh Mudjiman, (2002) menyatakan bahwa jumlah makanan dan kandungan gizi yang seimbang dengan kebutuhan ikan merupakan hal yang penting bagi kehidupan ikan untuk melakukan metabolisme dan pertumbuhan. Hasil pengamatan kelangsungan hidup benih Ikan Mas (Cyprinus carpio) pada masingmasing perlakuan terdapat pada Gambar 4 berikut ini. 


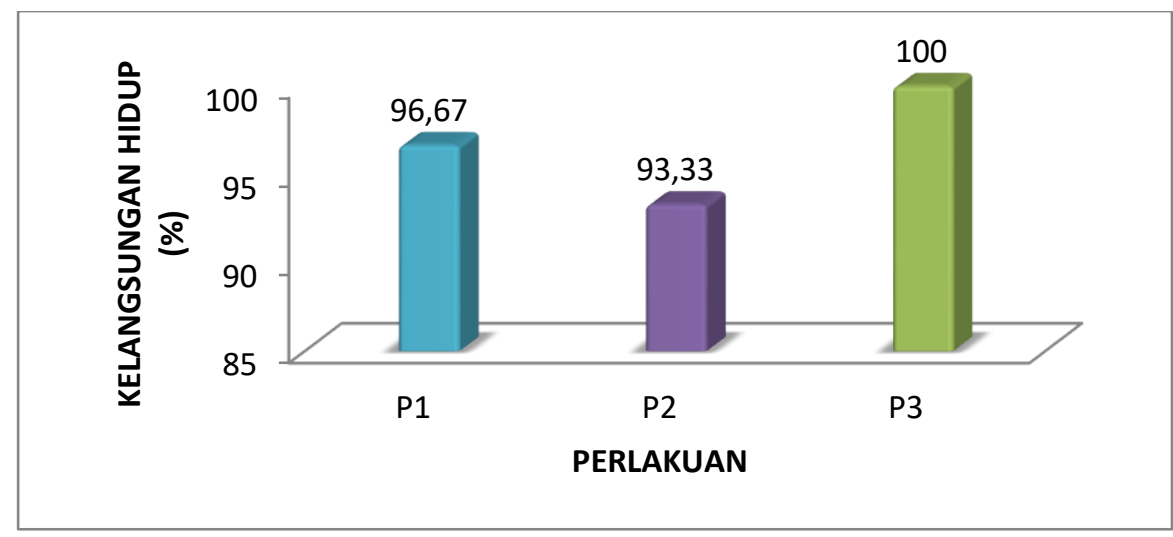

Gambar 4. Grafik Kelangsungan Hidup benih Ikan Mas (Cyprinus carpio)

Dapat dilihat dari Gambar 4 menunjukkan bahwa kelangsungan hidup tertinggi terdapat pada perlakuan P1 sebesar $100 \%$, diikuti perlakuan P1 yaitu 96,67\% dan kelangsungan hidup yang terendah ada pada perlakuan P2 sebesar 93,33\%. Hasil analisis ANSIRA kelangsungan hidup benih Ikan Mas (Cyprinus carpio) dengan perlakuan yang berbeda menunjukkan $F_{\text {hitung }}<\mathrm{F}_{\text {tabel }}$ dengan tingkat kepercayaan 5\% dimana $1,50<5,14$, yang artinya secara statistik berpengaruh tidak nyata antar perlakuan. Pada perlakuan P3 (Zeolit 75\% pasir dan ijuk) tingkat kelangsungan hidup tertinggi dari perlakuan lain yaitu $100 \%$. Hal ini diduga proses filterisasi yang optimal sehingga menghasilkan kualitas air yang bagus di dalam media pemeliharaan benih ikan mas dan dengan bertambahnya jumlah zeolit, maka penyerapan kandungan amonia menurun. Hal ini diperkuat oleh Mulyadi, et al (2014) yang menyatakan bahwa sistem resirkulasi dapat memperbaiki kualitas air di dalam media pemeliharaan yang sangat berpengaruh bagi kehidupan ikan selain kualitas air ada faktor lain yang menunjang kelulusanhidupan seperti pemberian pakan. Lebih lanjut Cahyo (2011) dalam Silaban (2012) mengatakan bahwa zeolite merupakan penyerap amonia yang sangat efisien dan juga menyediakan ruang untuk bakteri nitrifikasi dalam sistem sirkulasi.

\section{KESIMPULAN DAN SARAN \\ Kesimpulan}

Kesimpulan yang didapat dari penelitian ini adalah kandungan protein pada bahan organik sebelum difermentasi dalam kotoran kambing sebesar 8,70\%, Ampas tahu sebesar 6,90\%, Azolla pinnata sebesar 12,50 \% dan Ampas Kelapa sebesar 2,82\%. Selanjutnya, Kandungan protein pada bahan organik setelah difermentasi pada kotoran kambing sebesar 10,90\%, Ampas tahu sebesar 11,32 \%, Azolla pinnata sebesar 16,90 \% dan Ampas Kelapa sebesar $6,10 \%$. Sedangkan, pertambahan nilai kandungan protein Cacing Sutera yang terbaik yaitu pada perlakuan $\mathrm{MK}_{2}=11,6$ $\%$.

\section{Saran}

Saran untuk penelitian perlu dilakukan penelitian lanjutan untuk mengetahui jenis bakteri yang terdapat pada cacing Sutera hasil kultur menggunakan media bahan organik yang berbeda. 


\section{DAFTAR PUSTAKA}

Arianto, D, Harris, H., Yusanti, I.A., dan Arumwati, A. 2019. Padat Penebaran Berbeda Terhadap Kelangsungan Hidup, Fcr Dan Pertumbuhan Ikan Bawal Air Tawar (Colossoma macropomum) Pada Pemeliharaan Di Waring. Jurnal Ilmu-ilmu Perikanan dan Budidaya Perairan. Vol.14(2). Hlm : 14-20.

Arisanti, F., Arini, E. dan Elfitasari, T. 2013. Pengaruh Kepadatan yang Jurnal Ilmu-ilmu Perikanan dan Budidaya Perairan. Vol.15(1) : 1-9. Berbeda Terhadap Kelulushidupan dan Pertumbuhan Ikan Mas (Cyprinus carpio) Sistem Resirkulasi dengan Filter Arang. Journal of Aquaculture Management and Technology. Vol.2(4) : 139-144.

Arunde, E., Hengki, Sinjal, H. J., Monijung, R. D. D. 2016. Pengaruh Penggunaan Substrat Yang Berbeda Terhadap Daya Tetas Telur Dan Sintasan Hidup Larva Ikan Lele Sangkuriang (Clarias Sp). Jurnal Budidaya Perairan. Vol.4(1) : 715.

DOI: https://doi.org/10.35800/bdp. $\underline{4.1 .2016 .12318 .}$.

Effendi, M.I. 1979. Metode Biologi Perikanan. Yayasan Dwi Sri. Bogor. 112.

Effendi. 1997. Biologi Perikanan. Yayasan Pustaka Nusantara. Yogyakarta.

Hanafiah, K, A. 2011. Teori dan Aplikasi Rancangan Percobaan. Raja Grafindo Persada. Jakarta.
Hafiz, M., Mutiara, D., Haris, R.B.K., Pramesthy, T.D., Mulyani, R., dan Arumwati. A. 2020. Analisis Fotoperiode Terhadap Kecerahan Warna, Pertumbuhan Dan Kelangsungan Hidup Ikan Komet (Carassius auratus). Jurnal Ilmuilmu Perikanan dan Budidaya Perairan. Vol.15(1) : 1-9. DOI: http://dx.doi.org/10.31851/jip bp.v15i1.4287.

Haris, R.B.K., dan Yusanti, I.A. 2018. Studi Parameter Fisika Kimia Air Untuk Keramba Jaring Apung Di Kecamatan Sirah Pulau Padang Kabupaten Ogan Komering Ilir Provinsi Sumatera Selatan. Jurnal Ilmu-ilmu Perikanan dan Budidaya Perairan. Vol.14(2). Hlm : 57-62. DOI: http://dx.doi.org/10.31851/jip bp.v13i2.2434.

Kordi, M.G.H. K dan Tancung. B. A. 2007. Pengelolaan Kualitas Air dalam Budidaysa Perairan. Penerbit Rineka Citra. Jakarta. 208.

Lesmana, D. S. 2004. Kualitas Air Untuk Ikan Hias Air Tawar. Penebar Swadaya. Jakarta. 88.

Mulyadi, M., Tang, U., dan Yani, E.S. 2014. Sistem Resirkulasi Dengan Menggunakan Filter Yang Berbeda Terhadap Pertumbuhan Benih Ikan Nila (Oreochromis niloticus). Jurnal Akuakultur Rawa Indonesia. Vol.2(2) : 117-124. DOI: https://doi.org/10.36706/jari. v2i2.2079.

Mudjiman, A. 2002. Makanan Ikan. Penebar Swadaya. Jakarta. 100-151 hlm. 
Ramadhan, R., dan Yusanti, I.A. 2020. Studi Parameter Studi Kadar Nitrat Dan Fosfat Perairan Rawa Banjiran Desa Sedang Kecamatan Suak Tapeh Kabupaten Banyuasin. Jurnal Ilmu-ilmu Perikanan dan Budidaya Perairan. Vol 15(1) : 3741.

DOI: http://dx.doi.org/10.31851/jip bp.v15i1.4407.

Silaban, T. F., Santoso, L., dan Suparmono, S. 2012. Dalam Peningkatan Kinerja Filter Air Untuk Menurunkan Konsentrasi Amonia Pada Pemeliharaan Ikan Mas (Cyprinus carpio). Journal Rekayasa dan Teknologi Budidaya Perairan. Vol.1 (1) : 47-56.

Suandi, M., Mulyadi, M., dan Putra, I. 2019. Pengaruh Jumlah Zeolit Berbeda Terhadap Pertumbuhan Ikan Patin Siam (Pangasius hypopthalmus) Dengan Sistem Resirkulasi. Jurnal JOMFAPERIKA. Vol.6(1) 1-10.

Supriaddin, S. Priyono, J., dan Cokrowati, N. 2013. Penggunaan Zeolit pada Media Pengangkutan Benih Nila (Oreochromis niloticus). Jurnal Perikanan Unram. Vol.1(2) : 47-51.

Handayani, I., Nofyan. E dan Wijayanti, M. 2014. Optimasi Tingkat Pemberian Pakan Buatan terhadap Pertumbuhan dan Kelangsungan Hidup Ikan Patin Jambal (Pangasius djambal). Jurnal Akuakultur Rawa Indonesia. 2 (2) : 175-187.

DOI: https://doi.org/10.36706/jari. $\mathrm{v} 2 \mathrm{i} 2.2102$.
Wihardi, Y., Yusanti, I.A dan Haris, R.B.K. 2014. Feminisasi pada Ikan Mas (Cyprinus carpio) dengan Perendaman Ekstrak Daun-Tangkai Buah Terung Cepoka (Solanum torvum) pada lama Waktu Perendaman Berbeda. Jurnal Ilmuilmu Perikanan dan Budidaya Perairan. Vol.9(1) : 23 - 28.

Yufika, Harris, H., dan Anwar, S. 2019. Penggunaan Substrat Yang Berbeda Terhadap Fekunditas, Derajat Penetasan Dan Kelangsungan Hidup Pada Pemijahan Ikan Maskoki (Carrasius auratus). Jurnal Ilmu-ilmu Perikanan dan Budidaya Perairan. Vol.14(2) : 3946. 